\title{
MASTR MASTER
}

\section{Radioisotope Distribution Program Progress Report for December 1976}

\author{
E. Lamb
}

\section{OAK RIDGE NATIONAL LABORATORY}




\section{DISCLAIMER}

This report was prepared as an account of work sponsored by an agency of the United States Government. Neither the United States Government nor any agency Thereof, nor any of their employees, makes any warranty, express or implied, or assumes any legal liability or responsibility for the accuracy, completeness, or usefulness of any information, apparatus, product, or process disclosed, or represents that its use would not infringe privately owned rights. Reference herein to any specific commercial product, process, or service by trade name, trademark, manufacturer, or otherwise does not necessarily constitute or imply its endorsement, recommendation, or favoring by the United States Government or any agency thereof. The views and opinions of authors expressed herein do not necessarily state or reflect those of the United States Government or any agency thereof. 


\section{DISCLAIMER}

Portions of this document may be illegible in electronic image products. Images are produced from the best available original document. 
This report was prepared as an account of work sponsored by the United States Government. Neither the United States nor the Energy Research and Development Administration/United States Nuclear Regulatory Commission, nor any of their employees, nor any of their contractors, subcontractors, or their employees, makes any warranty, express or implied, or assumes any legal liability or responsibility for the accuracy, completeness or usefulness of any information, apparatus, product or process disclosed, or represents that its use would not infringe privately owned rights. 
Contract No. W-7405-eng-26

OPERATIONS DIVISION

RADIOISOTOPE DISTRIBUTION PROGRAM PROGRESS REPORT FOR DECEMBER 1976

E. Lamb

Work Sponsored by

ERDA Division of Biomedical and Environmental Research
$-$

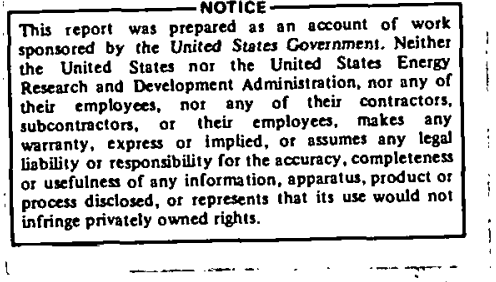

\section{Date Published - February 1977}

NOTICE This documant contains information of a preliminary nature. It is subject to revision or correction and therefore does not represent a finel report.

OAK RIDGE NATIONAL LABORATORY

Oak Ridge, Tennessee 37830

operated by

UNION CARBIDE CORPORATION

for the

ENERGY RESEARCH AND DEVELOPMENT ADMINISTRATION

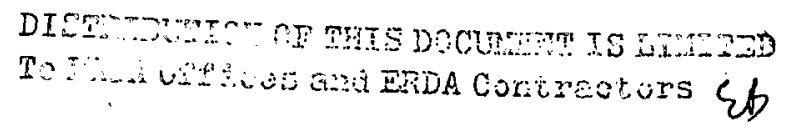




\section{THIS PAGE}

WAS INTENTIONALLY

LEFT BLANK 
CONTENTS

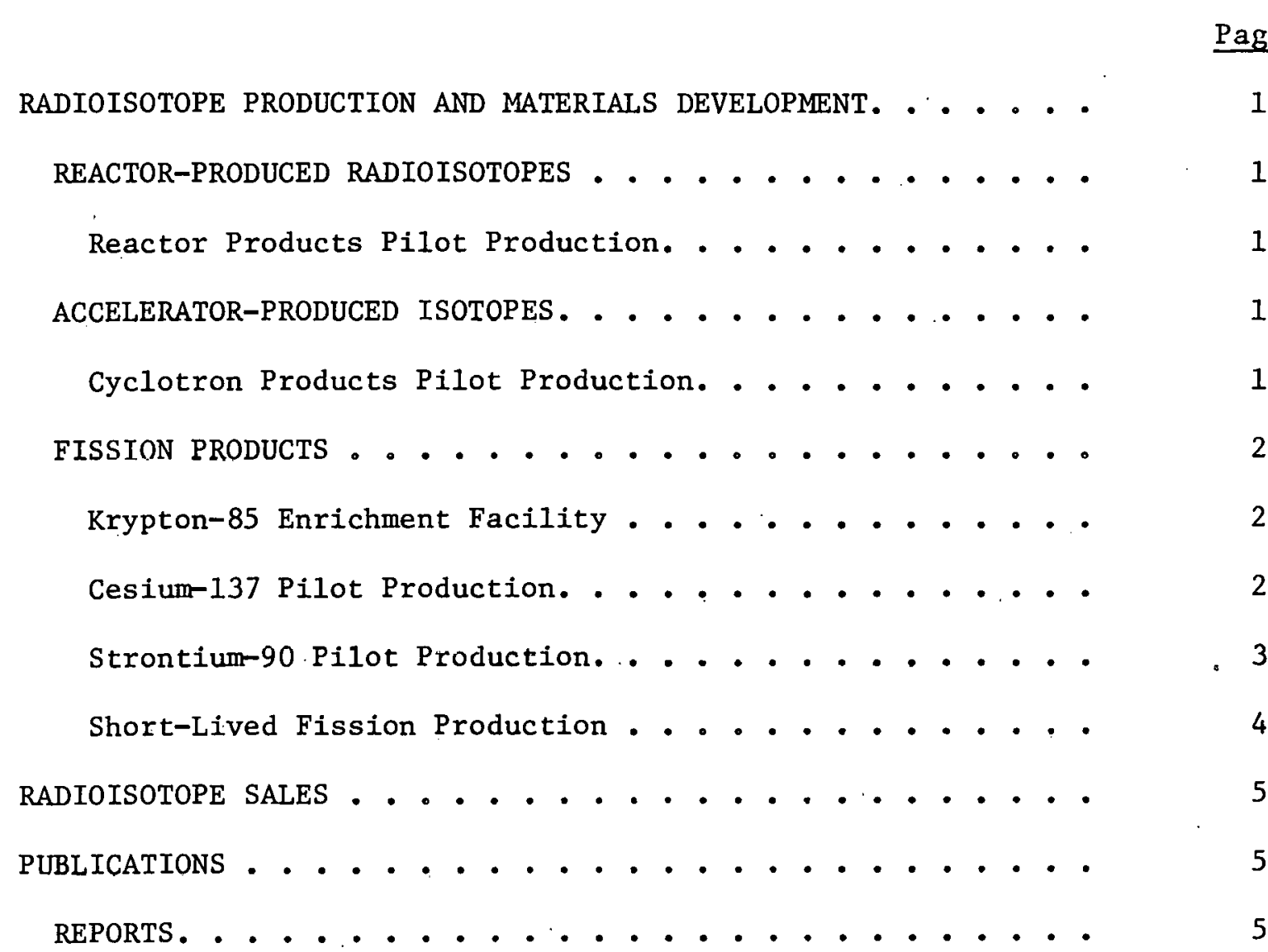




\section{RADIOISOTOPE DISTRIBUTION PROGRAM \\ PROGRESS REPORT FOR DECEMBER 1976}

$$
\text { E. Lamb }
$$

\section{RADIOISOTOPE PRODUCTION AND MATERIALS BEVELOPMENT}

REACTOR-PRODUCED RADIOISOTOPES

Reactor Products Pilot Production (R. W. Schaich)

(Production and Inventory Accounts)

$\frac{\text { Processed Units }}{\text { Radioisotope Amount (mCi) }}$

Calcium-47

\section{ACCELERATOR-PRODUCED -ISOTOPES}

Cyclotron Products Pilot Production (M. R. Skidmore)

(Production and Inventory Accounts)

December 1976 ORNL 86-Inch Cyclotron runs for ORNL and non-ORNL programs are given in Table 1.

Table 1. Cyclotron Irradiations and Runs for December 1976

\begin{tabular}{llcl}
\hline Date & Product & Target & Total Time Total \\
(hr:min)
\end{tabular}

nRNT, Programs

None

Non-ORNL Prngrams

\begin{tabular}{|c|c|c|c|c|c|c|c|}
\hline $\begin{array}{l}12-10-76 \\
12-14-76 \\
12-16-76 \\
12-21-76 \\
12-22-76 \\
12-28-76\end{array}$ & $\begin{array}{l}\text { New } \\
\text { New } \\
\text { New } \\
\text { New } \\
\text { New } \\
\text { New }\end{array}$ & $\begin{array}{l}\text { England } \\
\text { England } \\
\text { England } \\
\text { England } \\
\text { England } \\
\text { England }\end{array}$ & $\begin{array}{l}\text { Nuclear } \\
\text { Nuclear } \\
\text { Nuclear } \\
\text { Nuclear } \\
\text { Nuclear } \\
\text { Nuclear }\end{array}$ & $\begin{array}{l}\text { Gallium-67 } \\
\text { Gallium-67 } \\
\text { Cobalt-57 } \\
\text { Gallium-67 } \\
\text { Germanium-68 } \\
\text { Callium-67 }\end{array}$ & $\begin{array}{l}\text { Zinc-68 } \\
\text { Zinc-68 } \\
\text { Nicke1-58 } \\
\text { Zinc-6! } \\
\text { Ga1lium } \\
\text { Zinc-68 }\end{array}$ & $\begin{array}{l}14: 15 \\
53: 15 \\
46: 30 \\
48: 15 \\
13: 15 \\
50: 15\end{array}$ & $\begin{array}{r}2,330 \\
8,180 \\
8,402 \\
7,430 \\
2,279 \\
7,730 \\
\end{array}$ \\
\hline & & & & & & $225: 45$ & $\$ 36,251$ \\
\hline
\end{tabular}




\section{Cyclotron Operations}

During the month of December the cyclotron operated a total of 220 hours. Two runs were interrupted due to equipment failure, with one of the runs being completed on schedule. On December 1, 1976 we were unable to apply the RF to the dees. Sparking was noted from the south dee to the southeast liner wall. The cyclotron was let down to air and a crack in the liner was detected by visual inspection. The dees were removed and the crack in the liner was welded. The repairs were completed. December 8; 1976 and operations were resumed. A short outage occurred December 16, 1976 due to a shorted coupling capacitor.in the oscillator system.

\section{FISSION PRODUCTS}

\section{Krypton-85 Enrichment Facility (R. W. Sahaich)}

The ${ }^{85} \mathrm{Kr}$ enrichment colums operated satisfactorily during the month of December. Unloading operations were completed on $50 \%$ of the system during December. Analyses of the products were incomplete at the time of this report. A one-month maintenance period will be initiated on the columns that were unloaded. At the end of this period the second half of the system will be unloaded and the products analyzed:

Cesium-137 Pilot Production (R. W. Schaich)

(Production and Inventory Accounts)

1. Process Status

Process equipment is in standby status.

2. Operational Summary

\section{Product linventory}

(Decay calculated through August 31, 1976)

Inventory Material

Cesium-137 chloride powder
Amount (Sii)

$\underline{36,500}$ 
Non-Inventory Material

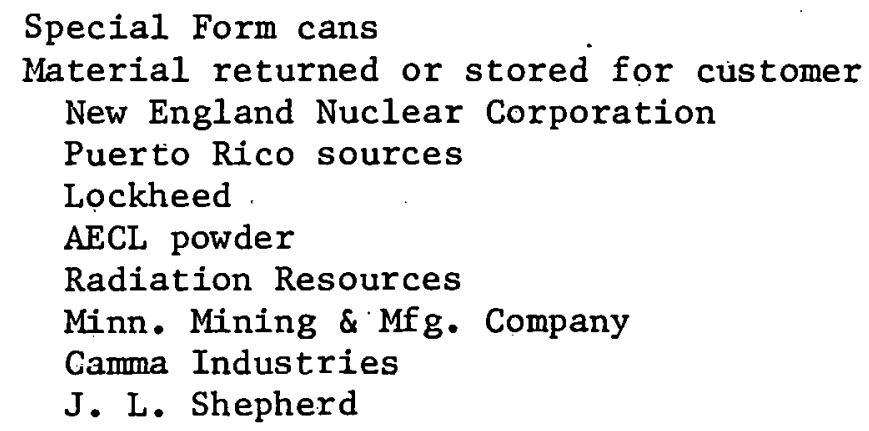

$0 \quad 0 \quad 11 \quad 1,720$
Amount (Ci)

$\begin{array}{r}4,500 \\ \\ 3,400 \\ 8,100 \\ 20,100 \\ 73,200 \\ 19,700 \\ 8,500 \\ 8,600 \\ 14,100 \\ \hline 160,200 \\ \hline\end{array}$

196,700

\section{Current Orders}

All orders on hand havo been completed and the material placed into storage awaiting receipt of release for the material.

Strontium-90 Pilot Production (R. W. Schaich) (Production and Inventory Accounts).

\section{Process Status}

The 20,000 curle ${ }^{90} \mathrm{Sr}$ heat source that was fabricated in November, 1976 for SNAM Progetti, Italy has been delayed until agreement can be reached on the weld penetration for the outer capsule. 
Product Inventory

(Decay calculated through August 31, 1976)

Inventory Material

${ }^{90} \mathrm{Sr}$ titanate powder $( \pm 5 \%)$

Sources in fabrication.

RCA source

${ }^{90} \mathrm{Sr}$ silicate powder (est.)

Stock powder cans
Amount (Ci)

77,000

20,000

57,300

28,000

3,790

186,090

Amount (Ci)

Non-Inventory Material

Calorimeter Standards

FPDL recovery material

Quehanna recovery material

Weather Bureau source

SIJAP - .7.B

SNAP $-7 C$

SNAP-7D

SNAP material purchase ${ }^{a}$
4,900

19,700

44,000

11,700

160,200

25,200

146,600

254,500

666,800

852,890

TOTAL INVENTORY AND NON-INVENTORY MATERILT

${ }^{d}$ Strontium-90 purchased under DRRD program.

Fabrication 3umulay

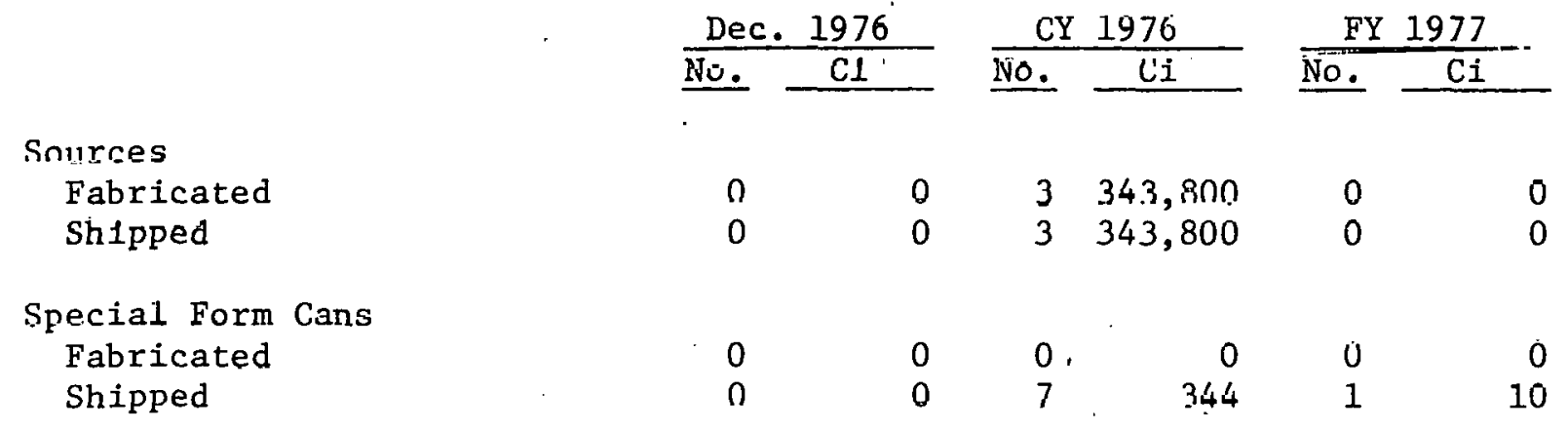

Short-Lived Fission Production (R. W. Schaich)

(Production and Inventory Accounts)

\section{Isotope}

Xenon-133

Iodine-131

Niobium-95

Yttrium-91
Number of Batches

4

1

1

1
Amount (Ci)

2600

18

2 


\section{RADIOISOTOPE SALES}

$$
\text { J.E. Ratledge }
$$

Shipments made during the month that may be of interest are listed below: Customer Isotope

Amount

\section{Large Quantities}

Saunders-Roe, England

New England Nuclear Corporation American Atomics Self-Powered Lighting, Ltd. KMS Fusion, Inc. ICN Pharmaceuticals.

\author{
Tritium \\ Tritium \\ Tritium \\ Tritium \\ Tritium \\ Tritium
}

$5,000 \mathrm{Ci}$
$8,000 \mathrm{Ci}$
$6,000 \mathrm{Ci}$
$2,000 \mathrm{Ci}$
$1,001 \mathrm{Ci}$
$1,000 \mathrm{Ci}$

Withdrawn Items

Cleveland Metropolitan General Hospital Iodine-131

$50 \mathrm{mCi}$

\section{Items Used in Cooperative Programs}

University of Southern California

Platinum-195m

$30 \mathrm{mCi}$

The radioisotope sales and shipments for the last three months of 1975 and the first three months of fiscal year 1977 are given. in Table 2.

Table 2. Radioisotope Sales and Shipments

\begin{tabular}{|c|c|c|c|c|}
\hline Item & \multicolumn{2}{|c|}{$\begin{array}{c}10-1-75 \text { thru } \\
12-31-75\end{array}$} & \multicolumn{2}{|c|}{$\begin{array}{c}10-1-76 \text { thru } \\
12-31-76\end{array}$} \\
\hline $\begin{array}{l}\text { Inventory items } \\
\text { Major products } \\
\text { Radioisotope services } \\
\text { Cyclotron irradiations } \\
\text { Miscellaneous processed materials. } \\
\text { Packing and shipping }\end{array}$ & $\$$ & $\begin{array}{l}83,694 \\
10,045 \\
23,570 \\
54,699 \\
15,609 \\
25,395 \\
\end{array}$ & $\$$ & $\begin{array}{r}71,013 \\
27,154 \\
57,688 \\
116,842 \\
20,039 \\
47,634 \\
\end{array}$ \\
\hline Total & $\$$ & 213,012 & $\$$ & 340,370 \\
\hline Number of shipments & & 685 & & 602 \\
\hline
\end{tabular}

\section{PUBLICATIONS}

\section{REPORTS}

E. Lamb, Radioisotope Distribution Progrom Progress Report for November 1976, ORNL/TM-5748, Oak Ridge National Laḅoratory (December 1976)。 


\section{THIS PAGE}

WAS INTENTIONALLY

LEFT BLANK 
ORNL/TM-5791

INTERNAL DISTRIBUTION

1. E. E. Beauchamp

2. T. A. Butler

3. F. N. Case

4. W. R. Casto

5. J. A. Cox

6. R. F. Hibbs

7. E. Lamb

8. H. H. Nichol

9. C. L. Ottinger

10. J. K. Poggenburg

11. H. Postma
12. M. E. Ramsey

13. J. E. Ratledge

14. C. R. Richmond

15. A. F. Rupp

16. R. W. Schaich

17. M. R. Skidmore

18. M. J. Skinner

19-20. Central Research Library

21-22. Laboratory Records Department

23. Laboratory Records - RC

24. Document Reference Section

\section{EXTERNAL DISTRIBUTION}

25. B. J. Dropesky, LASL, Los Alamos, New Mexico

26-27. J. H. Jarrett, PNL, Richland, Washington

28. D. K. Jones, Richland Operations Office, Richland, Washington

29. J. N. Maddox, EKDA-DBER, Washington, D.C.

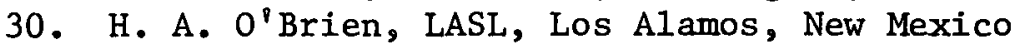

31. F. J. Skozen (Krizek), Argonne Cancer Research Hospita1, Chicago, I11.

32. L: G. Stang, Jr., BNL, New York

33-34. R. W. Wood, ERDA-DBER, Washington, D.C.

35. Donner Laboratory Library, Univ. of California, Berkeley, Calif., 94720

36. Research and Technical Support Division, ORO

37-38. Technical Information Center 